\title{
Expression and antigenic analysis of the recombinant TRP36 protein from Ehrlichia canis São Paulo strain for serologic tests
}

\section{Expressão e análise antigênica da proteína RTP36 recombinante da amostra São Paulo de Ehrlichia canis para testes sorológicos}

Miguel Ângelo da Silva Medeiros ${ }^{1,2}$; Maria Helena da Silva3; Maria Adelaide do Valle Matta4;

Eliane de Oliveira Ferreira5* (1); Sérgio Lisboa Machado6; João Fábio Soares; ; Marcelo Bahia Labruna ${ }^{8}$; Helena Keiko Toma6; Márcia de Souza Xavier2; Maria de Nazareth Silveira Leal de Meirelles ${ }^{4,1,+}$; Nádia Regina Pereira Almosny²

\author{
Faculdade de Veterinária, Universidade Castelo Branco - UCB, Rio de Janeiro, RJ, Brasil \\ ${ }^{2}$ Departamento de Patologia Clínica Veterinária, Faculdade de Veterinária, Universidade Federal Fluminense - UFF, Niterói, RJ, Brasil \\ ${ }^{3}$ Departamento de Imunologia, Instituto de Microbiologia Paulo de Góes, Universidade Federal do Rio de Janeiro - UFRJ, \\ Rio de Janeiro, RJ, Brasil \\ ${ }^{4}$ Laboratório de Ultraestrutura Celular, Instituto Oswaldo Cruz, Fundação Oswaldo Cruz, Rio de Janeiro, RJ, Brasil \\ ${ }_{5}^{5}$ Departamento de Microbiologia Médica, Instituto de Microbiologia Paulo de Góes, Universidade Federal do Rio de Janeiro - UFRJ, \\ Rio de Janeiro, RJ, Brasil \\ ${ }^{6}$ Laboratório de Diagnóstico Molecular e Hematologia, Faculdade de Farmácia, Universidade Federal do Rio de Janeiro - UFRJ \\ Rio de Janeiro, RJ, Brasil \\ 7 Programa de Pós-graduação em Ciências Veterinárias, Universidade Federal do Rio Grande do Sul - UFRS, Porto Alegre, RS, Brasil \\ ${ }^{8}$ Departamento de Medicina Veterinária Preventiva e Saúde Animal, Faculdade de Medicina Veterinária e Zootecnia, Universidade de \\ São Paulo - USP, São Paulo, SP, Brasil \\ †In memoriam
}

How to cite: Medeiros MAS, Silva MH, Valle Matta MA, Ferreira EO, Machado SL, Soares JF, et al. Expression and antigenic analysis of the recombinant TRP36 protein from Ehrlichia canis São Paulo strain for serologic tests. Braz J Vet Parasitol 2020; 29(3): e005820. https://doi.org/10.1590/S1984-29612020051

\begin{abstract}
Ehrlichia canis is the main etiological agent of canine monocytic ehrlichiosis (CME), a globally canine infectious disease. In Brazil, CME is considered to be endemic, and its prevalence can reach 65\% in some states. The diagnosis of ehrlichiosis is important for treatment and epidemiological purposes. The E. canis TRP36 (Tandem Repeat Protein) protein elicits the earliest acute-phase antibody response observed during the course of the disease. This study aimed to generate the recombinant TRP36 protein from E. canis São Paulo strain and to evaluate its potential as a tool for the serologic diagnosis of CME. The E. canis São Paulo isolate was cultivated in DH82 lineage cells, and its genomic DNA was obtained. The bacterial DNA fragment encoding the entire ORF of TRP36 was cloned into the PBAD/Thio-TOPO vector and transformed into Escherichia coli DH10B competent cells with the trp36-bearing plasmid for protein expression. To evaluate the protein antigenicity, 16 canine serum samples were previously tested (by PCR and the commercial SNAP ${ }^{\circledR} 4 \mathrm{Dx}{ }^{\circledR}$ serological test). The results were in accordance with the SNAP 4 Dx ${ }^{\circledast}$ test. Experiments using this recombinant protein as an antigen, targeting the development of a serologic test based on ELISA methodology, are the next step to produce a reliable, affordable and useful diagnostic tool for CME in Brazil.
\end{abstract}

Keywords: Ehrlichia canis, TRP36 protein, epidemiology, diagnostic, serologic tests.

\begin{abstract}
Resumo
Ehrlichia canis é o principal agente etiológico da erliquiose monocítica canina (EMC), uma doença infecciosa canina globalmente dispersa. No Brasil, a EMC é considerada endêmica, e a infecção pode atingir $65 \%$ em cães em alguns estados. O diagnóstico de erliquiose é importante para fins de tratamento e epidemiológicos. A proteína TRP36 de E. canis leva a uma resposta humoral com produção de anticorpos em fase aguda, encontrada
\end{abstract}


durante o curso da doença. O objetivo deste estudo foi obter a proteína TRP36 recombinante da amostra São Paulo de E. canis e avaliar seu potencial como ferramenta para o diagnóstico sorológico da CME. O isolado de E. canis São Paulo foi cultivado em células da linhagem DH82 e o DNA genômico foi obtido. O fragmento de DNA bacteriano que codifica toda a ORF de TRP36 foi clonado no vetor PBAD / Thio-TOPO e transformado em células competentes Escherichia coli DH10B, com o plasmídeo portador de trp36 para expressão de proteínas. Para avaliar a antigenicidade da proteína, 16 amostras de soro canino foram previamente analisadas (por PCR e teste sorológico comercial SNAP ${ }^{\circledR} 4 \mathrm{Dx} \mathrm{x}^{\circledR}$ ). Os resultados estavam de acordo com o teste $\mathrm{SNAP}^{\circledR} 4 \mathrm{Dx} \mathrm{x}^{\circledR}$. Os experimentos que utilizam essa proteína recombinante como antígeno, visando ao desenvolvimento de um teste sorológico baseado no ELISA, são o próximo passo para produzir um teste de diagnóstico confiável, acessível e útil para o diagnóstico da EMC no Brasil.

Palavras-chave: Ehrlichia canis, proteína TRP36, epidemiologia, diagnóstico, testes sorológicos.

\section{Introduction}

Ehrlichia canis, an Anaplasmataceae agent with a ubiquitous distribution, is the etiological agent of canine monocytic ehrlichiosis (CME), a globally dispersed canine infectious disease (Ristic \& Holland, 1993). The disease is transmitted by the tick vector Rhipicephalus sanguineus sensu lato (Latreille) (Donatien \& Lestoquard, 1935; Groves et al., 1975), which is more active in warm seasons (Harrus \& Waner, 2011). This is a determinant factor for the occurrence of high-incidence areas of the disease in tropical and subtropical regions (Ristic \& Holland, 1993). CME is considered endemic in dogs from numerous regions of Brazil (Vieira et al., 2011) with the frequency of infected dogs reaching as high as $65 \%$ in some regions (Aguiar et al., 2013). Several factors contribute to this high prevalence, such as the extensive distribution of $R$. sanguineus throughout urban areas, deficient dog immunity to E. canis, and persistence of E. canis infections in canines (Cohn, 2003; Aguiar et al., 2007a, b). Ehrlichia canis expresses immunoreactive glycoproteins with serial repeat regions (tandem repeat protein; TRP) in its genome (Doyle et al., 2006; McBride et al., 2011). These proteins are species-specific antigens (Cardénas et al., 2007) that are closely related to the parasite-host interaction. For instance, the 36-kDa membrane glycoprotein (TRP36) contains a major antibody epitope in the tandem repeat region (12 to 15 replicates) and has been associated with adhesion and internalization, actin nucleation, and immune evasion during infection in the host (Zweygarth et al., 2014). Conversely, the gene encoding the 19-kDa membrane glycoprotein (gp19) is more conserved and contains epitope regions (McBride et al., 2007). Another immunogenic glycoprotein is the 28-kDa outer surface protein (P28), which is encoded by a multigenic locus with at least 22 alleles of the p28 gene (p28-1 to p28-22) in the genome of E. canis (McBride et al., 1999).

The diagnosis of the disease can be challenging due to its different phases and multiple clinical manifestations. CME should be suspected when a compatible history (living in or traveling to an endemic region, previous tick exposure), typical clinical signs and characteristic hematological and biochemical abnormalities are present. Traditional diagnostic techniques (hematology, cytology, serology and isolation) are valuable diagnostic tools for CME; however, a definitive diagnosis of $E$. canis infection requires molecular techniques (Kuehn \& Gaunt, 1985; O'Connor et al., 2006; Harrus \& Waner, 2011), such as polymerase chain reaction (PCR) and sequencing (McBride et al., 1996). Serological tests that detect a dog's antibodies provide relatively rapid and reliable results to confirm suspected cases before the administration of antibiotic therapy (O'Connor et al., 2006; Vieira et al., 2011). Although the indirect fluorescent antibody (IFA) test is considered a gold standard, it has limitations, including serologic cross-reactivity with other Ehrlichia species and the requirements of expensive reagents and laboratory equipments (O'Connor et al., 2006; Aguiar et al., 2007b). IFA also depends on the culture of the organism in a cell culture lineage to produce the ehrlichial antigens. The E. canis Oklahoma strain grown in DH82 cells has been used in a commercial test (VRMD Pullman ${ }^{\circledR}$ ) (Nyindo et al., 1971).

Diagnostic tests based on enzyme-linked immunosorbent assays (ELISA) can also be used to confirm E. canis infection, and commercial kits for the detection of $E$. canis-reactive IgG antibodies are also available, including a dotblot ImmunoComb ${ }^{\circledR}$ (Biogal Galed Laboratories, Israel) and SNAP ${ }^{\circledR} 4$ Dx ${ }^{\circledast}$ (IDEXX Laboratories Inc. USA). The SNAP ${ }^{\circledR}$ Dx ${ }^{\circledR}$ test employs synthetic peptides derived from the major immunodominant E. canis proteins P30 and P30-1 as antigens for $E$. canis antibody detection (O'Connor et al., 2006).

$\mathrm{PCR}$ and sequencing are sensitive methods for detecting and characterizing $E$. canis DNA, and detection can be achieved early as 4-10 days post inoculation. These assays are based on targeting different genes 
(16S rRNA, p28, p30, dsb, and VirB9), but the 16S rRNA and p30-based PCR assays are most commonly used. In fact, p30 PCR is more sensitive because $E$. canis presents multiple copies of this gene (Ohashi et al., 1998).

E. canis proteins obtained by DNA recombinant technology have proven to be useful as antigens for the serodiagnosis of canine ehrlichiosis (McBride et al., 2001; Cardénas et al., 2007). E. canis is a obligatory intracellular Gram-negative coccus living in blood monocytes or tissue macrophages as microcolonies inside membrane-lined vacuoles (morulae) of host origin (Ristic \& Holland, 1993). Isolates have been established in a canine monocyte cell line (DH82 cells) (Wellman et al., 1988). Multiple E. canis isolates have been propagated in the laboratory and established as stable cultures in the following areas of Brazil: Rio de Janeiro (Torres et al., 2002), Jaboticabal County in the state of São Paulo (Aguiar et al., 2007b), São Paulo (Aguiar et al., 2008), and Uberlândia in southeastern Brazil (Alves et al., 2014). More recently, several isolates have been established in all the geopolitical regions of Brazil (Aguiar et al., 2013).

The $E$. canis São Paulo isolate came from a naturally infected dog and has been molecularly characterized by DNA sequencing of portions of the ehrlichial dsb, 16S rRNA, and trp36 genes (Doyle et al., 2005; Aguiar et al., 2008). The $d s b$ and $16 \mathrm{~S}$ rRNA sequences were shown to be identical to North American strains and even to strains from the African, Asian, and European continents (Aguiar et al., 2008). Subsequently, new isolates were obtained from different Brazilian regions, and their genetic diversity was examined based on amino acid sequences, which were deduced from the nucleotide sequence of the trp36 gene (Doyle et al., 2005; Aguiar et al., 2013). Ferreira et al. (2014) also performed a phylogenetic study based on the trp36 gene sequences of $E$. canis strains infecting dogs in Rio de Janeiro.

The TRP36 protein, encoded by the trp36 gene (DQ146154 in GenBank) (Doyle et al., 2005), is differentially expressed only in the dense-cored morphological form of Ehrlichia, in which the protein is exposed on the cell surface and secreted (Doyle et al., 2006). The amino acid sequence of the TRP36 protein (formerly GP36) of the São Paulo strain contains 18 repeats of a conserved amino acid sequence, TEDSVSAPA, and it is classified as part of the US genogroup, to which North American and Cameroonian isolates belong (Doyle et al., 2005). A different sequence (ASVVPEAE) was identified in some E. canis isolates from the midwestern, northeastern and southern regions of Brazil, representing a novel genogroup based on the TR amino acid sequence of TRP-36 (Aguiar et al., 2013). In addition, using synthetic peptides reproducing the TR regions of TRP36, Aguiar et al. (2016) distinguished infections and detected coinfections by $E$. canis displaying distinct genotypes in sera from dogs naturally or experimentally infected with E. canis, and their study identified the seroprevalence of genotypes of this obligatory-intracellular bacterium. An ELISA using a synthetic TRP36 peptide based on the TR regions was used to detect genotype-specific E. canis-exposure in Brazilian dogs. The E. canis TRP36 protein, together with TRP19, elicits the earliest acute-phase antibody response observed in the course of disease (Doyle et al., 2006). TRP36 is a surface protein that is recognized early in the infection process, so the whole protein can be a relevant antigen for serum diagnosis (McBride et al., 2003; Doyle et al., 2006; Cardénas et al., 2007).

Considering the universality of this major ehrlichial immunoreactive protein that is recognized by antibodies in the earliest acute phase of CME, the present study aimed to produce a TRP36 recombinant fusion protein from an autochthonous $E$. canis strain for use as an antigen in immunodiagnostic assays.

\section{Material and Methods}

\section{Cell culture and maintenance of $E$. canis}

The E. canis isolate designated as the São Paulo strain was maintained at the University of São Paulo, São Paulo, Brazil, and used in this study. A frozen $\left(-80^{\circ} \mathrm{C}\right)$ stock sample of infected DH82 cells was thawed and added to uninfected DH82 monolayers in a $25 \mathrm{~cm}^{2}$ culture flask. The cells were cultured in Dulbecco's modified Eagle's medium (DMEM-Sigma Aldrich, St Louis, MO. USA) containing 2.5\% heat-inactivated iron-supplemented calf serum (HyClone Laboratories, Logan, UT) at $37{ }^{\circ} \mathrm{C}$ in a BOD (Thermo Scientific) $\left(5 \% \mathrm{CO}_{2}\right)$ atmosphere. The culture was maintained under the same conditions, and the culture medium was partially (20\%) replaced every 2-3 days. The cell cultures were monitored twice a week for the presence of morulae by Diff-Quik staining (Laborclin, Pinhais, PR, Brazil) and the presence of ehrlichial DNA by PCR. DH82 cell cultures with $90 \%$ to $100 \%$ E. canis infection rates were used for ehrlichial DNA extraction. 


\section{Dog sera}

All serum samples were obtained from dogs during the vaccination campaign against rabies in Maricá Municipality, state of Rio de Janeiro, Brazil, in September of 2007. These serum samples were used to test the antigenicity of the recombinant TRP36. Animals were not selected according to any criteria, such as breed, age, sex, hygiene condition, comportment or habitat. The blood samples were collected in $5 \mathrm{~mL}$ vacuum tubes containing or lacking anticoagulant (EDTA, ethylenediaminetetraacetic acid), and subjected to serological tests and molecular diagnostics to detect possible $E$. canis infection. The sixteen serum samples used in this work were screened by immunological and molecular analyses and separated into two groups: 12 Ehrlichia-positive sera, according to the results obtained from one or both tests, and 4 Ehrlichia-negative sera, according to the results from both tests. The blood samples without anticoagulant were maintained at room temperature. After coagulation, the sera were separated by centrifugation and stored at $-20^{\circ} \mathrm{C}$ prior to immunological analyses using the commercial test Canine SNAP ${ }^{\circledR} 4 \mathrm{DX}^{\circledR}$ (IDEXX, Westbrook, Maine, USA) that detects antibodies against Ehrlichia canis, Anaplasma phagocytophilum, Borrelia burgdorferi and Dirofilaria immitis antigens. The DNA extraction for molecular diagnostics was performed using the GE Genomic Blood Purification Kit (Amersham Biosciences, Piscataway, USA).

\section{DNA extraction from $E$. canis cultured in DH82 cells}

The DNA extraction was preceded by a step for the purification of ehrlichial organisms, as described by Rikihisa (1991), with some modifications. Briefly, the infected DH82 cell suspensions were centrifuged at 10,000 x $g$ for $10 \mathrm{~min}$ at $4{ }^{\circ} \mathrm{C}$; the cell pellets were resuspended at $5 \times 10^{6} \mathrm{cell} / \mathrm{mL}$ in DMEM and subjected to ultrasonic disruption ( $5 \mathrm{~min}$ at $20 \mathrm{kHz}$ with the microtip of a W-380 ultrasonic processor (Heat Systems Ultrasonics, Farmingdale, NY). Unbroken cells and large cellular debris were pelleted by centrifugation at 1,500 x g for $30 \mathrm{~min}$; the supernatants were decanted and subjected to a second centrifugation step at $15,000 \mathrm{xg}$ for $10 \mathrm{~min}$ at $4^{\circ} \mathrm{C}$. The bacteria-containing pellet was used for DNA extraction with the Invisorb Spin Blood Mini Kit (Invitek GmbH, Berlin, Germany), according to the manufacturer's instructions. Each ehrlichial DNA sample was eluted in $100 \mu \mathrm{L}$ of TE buffer and stored at $-20{ }^{\circ} \mathrm{C}$ for PCR.

\section{PCR amplification of the Ehrlichia trp36 gene}

The oligonucleotide primers for the amplification of the E. canis trp36 gene were designed using PRIMER3 (http://frodo.wi.mit.edu/) (Rozen \& Skaletsky, 2000.) according to the sequence in GenBank, accession number DQ146154 (Doyle et al., 2005). The complete trp36 open reading frame, an approximately 1,002 bp fragment, was amplified by PCR with the oligonucleotide primers 1gp36SP (5'-ATGCTTCATTTAACAACAGA-3') and Rev1gp36SP (5'-TGTTGCTGCAGTAGCTGGAGC-3'). The amplification reaction mixture $(50 \mu \mathrm{L})$ consisted of: 3 to $5 \mathrm{ng} / \mathrm{mL}$ DNA, $1 \times$ Taq polymerase buffer, $2.5 \mathrm{mM} \mathrm{MgCl}$, $0.2 \mathrm{mM}$ of each deoxyribonucleotide (dATP, dGTP, dTTP, and dCTP), $1 \mathrm{pmol} / \mu \mathrm{L}$ of each primer and $1 \mathrm{U}$ of Taq polymerase (Invitrogen Corp. Carlsbad, CA). The thermal cycling profile was as follows: $95^{\circ} \mathrm{C}$ for $5 \mathrm{~min}$, and then 30 cycles of $94^{\circ} \mathrm{C}$ for $30 \mathrm{~s}, 43^{\circ} \mathrm{C}$ for $30 \mathrm{~s}$, and $72{ }^{\circ} \mathrm{C}$ for 1 min followed by a $72{ }^{\circ} \mathrm{C}$ extension for $10 \mathrm{~min}$ and $a 4^{\circ} \mathrm{C}$ hold; the PCR was conducted in the Veriti ${ }^{\circledR}$ Thermal Cycle (AB Applied Biosystems). The reaction mixtures were resolved by $0.8 \%$ (wt/vol) agarose gel electrophoresis. The amplicons were mixed with Blue Green Loading Dye (LGC Biotecnologia) at a pH 8.0 and subjected to electrophoresis in 1x TBE buffer ( $89 \mathrm{mM}$ Tris base, $89 \mathrm{mM}$ boric acid and $2 \mathrm{mM}$ EDTA) (110 V) in parallel with the molecular weight marker $1 \mathrm{~Kb}$ Plus DNA Ladder (Invitrogen Corporation, Carlsbad, Calif., USA). The DNA bands were visualized under UV light (Bio-Imaging Systems- MiniBis Pro, BioAmerica Inc.). The QIAquick gel extraction kit (QIAgen, Germany) was used to purify the DNA bands corresponding to the expected $900 \mathrm{bp}$ fragment from the agarose gel for the cloning and subsequent expression of the TRP36 fusion protein.

\section{DNA sequencing and analysis}

The PCR products corresponding to the expected size were purified using the Illustra ${ }^{\mathrm{TM}}$ GFXTM PCR DNA and Gel Band Purification Kit (GE Healthcare, Little Chalfont, Buckinghamshire, UK) prior to sequencing. The nucleotide sequences were analyzed using the Thermocycler Sequencing BigDye Terminator Kit (Applied Biosystems, Carlsbad, CA) according to the manufacturer's instructions and then electrophoresed in an ABI Prism 3130 Genetic Analyzer (Applied Biosystems, Carlsbad, CA). Each sequence obtained was analyzed using the Lasergene SeqMan 7.0 Module (DNAStar) (http:/www.DNAStar.com). 


\section{Cloning of the gene encoding the E. canis TRP 36 recombinant protein}

The PCR-amplified fragment was cloned into the PBAD-Thio TOPO expression vector (Invitrogen, Carlsbad, $\mathrm{CA}$, molecular mass $4.4 \mathrm{~Kb}$ ) at 22 to $25^{\circ} \mathrm{C}$ for 5 min. Escherichia coli DH10B (TOP10 One Shot Electrocompetent; Invitrogen) cells $(100 \mu \mathrm{L})$ were transformed with the trp36-bearing plasmid $(5 \mu \mathrm{L})$ using an electroporator (Eppendorf ${ }^{\circledR}$ Eporator ${ }^{\circledR}$, Germany) at $2.5 \mathrm{~V}$. The transformed cells were suspended in $1 \mathrm{~mL} \mathrm{SOC}$ medium (2\% tryptone, $0.5 \%$ yeast extract, $10 \mathrm{mM} \mathrm{NaCl}, 2.5 \mathrm{mM} \mathrm{KCl}, 10 \mathrm{mM} \mathrm{MgCl}, 10 \mathrm{mM} \mathrm{MgSO}_{4}$, and $20 \mathrm{mM}$ glucose), incubated at $37^{\circ} \mathrm{C}$ for $1 \mathrm{~h}$ with shaking $(250 \mathrm{rpm}$ ) and then plated onto LB agar (Luria-Bertani broth) containing $100 \mu \mathrm{g} / \mathrm{mL}$ ampicillin. After $18 \mathrm{~h}$ of incubation at $37^{\circ} \mathrm{C}$, ten isolated colonies were transferred to selective medium $(2.0 \mathrm{~mL} \mathrm{LB})$ and grown as independent cultures at $37^{\circ} \mathrm{C}$ overnight with shaking, followed by plasmid extraction using the alkaline method (Birnboim \& Doly, 1979). The plasmidial DNA extracts from 5 clones were subjected to electrophoresis on an agarose $(0.8 \%)$ gel to confirm the molecular size of the trp36-bearing plasmid. The positive clones were further screened by PCR with the sense primer 1 trp36SP (5'- ATGCTTCATTTA ACA ACAGA - $3^{\prime}$ ) and an antisense primer located in the vector ( $\mathrm{PBAD}$ reverse primer) provided in the Invitrogen kit.

\section{Expression of the E. canis TRP 36 recombinant protein}

Recombinant plasmids were first screened for the TRP36-fusion protein expression using L- (+)-arabinose as the inductor. After a small-scale experiment to determine the optimal concentration of the sugar, one positive clone was grown overnight in LB medium containing $100 \mu \mathrm{g} / \mathrm{mL}$ ampicillin at $37^{\circ} \mathrm{C}$ under shaking (250 rpm). This overnight culture was inoculated into $500 \mathrm{~mL}$ of LB medium in a $1 \mathrm{~L}$ culture flask for the large-scale expression experiment. The culture was maintained at $37^{\circ} \mathrm{C}$ under shaking until an $\mathrm{OD}_{550}$ of 0.5 . L-arabinose was then added to a final concentration of $0.002 \%$, and the culture was grown for $4 \mathrm{~h}$ at $25^{\circ} \mathrm{C}$ under shaking. After reaching the corresponding OD, cells were harvested by centrifugation $(9,500 \times \mathrm{g})$ for $20 \mathrm{~min}$ at $4{ }^{\circ} \mathrm{C}$. The pellet was suspended in phosphate buffer saline (PBS) at pH 7.4, and a $100 \mu \mathrm{L}$ sample was analyzed by $12 \%$ SDS-PAGE under denaturing and reducing conditions, as described by Laemmli (1970). The remainder of the preparation was centrifuged, and the pellet was resuspended in $10 \mathrm{~mL}$ of ice-cold binding buffer $(20 \mathrm{mM}$ sodium phosphate buffer, $\mathrm{pH} 7.8$, containing $500 \mathrm{mM} \mathrm{NaCl}$ and $10 \mathrm{mM}$ imidazole) plus lysozyme $(1 \mathrm{mg} / \mathrm{mL})$, mixed with microglass beads $(0.1 \mathrm{~mm})$ $\mathrm{V} / \mathrm{v}$, and subjected to three $10 \mathrm{~s}$ pulses at $10 \mathrm{~s}$ intervals in the Bead Beater (model 1107900, Biospec, Bartlesville, USA). After glass bead sedimentation, the supernatant was transferred to a Falcon tube to which DNase and RNase were added to a final concentration of 5 and $10 \mu \mathrm{g} / \mathrm{mL}$, respectively. The mixture was centrifuged to pellet the debris and the microbeads, and the supernatant was stored for the future isolation of the TRP36-fusion protein.

\section{Purification of the recombinant TRP36 protein by metal affinity chromatography}

The Ni-charged His•Bind Resin (Novagen, EMD Biosciences, Inc. Merck KGaA. Darmstadt, Germany) was washed with sterile water, equilibrated with ice-cold binding buffer and then mixed with cell lysate. After $1 \mathrm{~h}$ under slow rotation, the mixture was transferred to a glass column, and the flow-through was collected in $5 \mathrm{~mL}$ fractions. The column was then washed $3 x$ with $10 \mathrm{~mL}$ of buffer containing $60 \mathrm{mM}$ imidazole $(20 \mathrm{mM}$ Tris- $\mathrm{HCl}, \mathrm{pH} 7.9,500 \mathrm{mM}$ $\mathrm{NaCl}$ and $60 \mathrm{mM}$ imidazole), and the elution fractions were collected in three tubes. The recombinant protein was then eluted by applying a high-concentration imidazole elution buffer $(20 \mathrm{mM}$ Tris- $\mathrm{HCl}, \mathrm{pH} 7.9,500 \mathrm{mM} \mathrm{NaCl}$ and $500 \mathrm{mM}$ imidazole) and collected in $2 \mathrm{~mL}$ fractions. The elution fractions and the original supernatant were analyzed by SDS-PAGE, as described above. The E. coli DB10 clones, which are able to produce great quantities of the recombinant TRP36 from E. canis, are maintained at the Medical Microbiology Department of the Instituto de Microbiologia Paulo de Goes at UFRJ.

\section{ELISA}

The reactivity of antibodies in the sera of naturally infected dogs to the TRP36 recombinant protein was evaluated by an enzyme-linked immunosorbent assay (ELISA). Recombinant TRP36 $(10 \mu \mathrm{g} / \mathrm{mL})$ was diluted in PBS; the assay plate (Nunc-Immuno Plates with a Polysorp surface; Nunc, Roskilde, Denmark) wells were coated with $100 \mu \mathrm{L}$ containing the recombinant protein, except for column 1, which was coated with PBS only. The plate was incubated first for $1 \mathrm{~h}$ at $37^{\circ} \mathrm{C}$ and then overnight at $6^{\circ} \mathrm{C}$. Next, the plate was washed three times with $200 \mu \mathrm{L}$ of wash buffer (PBS), blocked with $100 \mu \mathrm{L}$ of blocking buffer (PBS-5\% nonfat milk) and incubated for $1 \mathrm{~h}$ at $37^{\circ} \mathrm{C}$. The serum samples were serially diluted in blocking buffer in 2-fold dilutions from 1:20 to 1:2,560, and $100 \mu \mathrm{L}$ of the diluted sera were added to duplicate test wells containing the antigen and blank wells containing no antigen. 
After incubation at $37{ }^{\circ} \mathrm{C}$ for $1 \mathrm{~h}$, the plate was washed, and $100 \mu \mathrm{L}$ of rabbit anti-dog IgG (whole molecule) peroxidase-conjugate (Sigma Chemical Co., Saint Louis, MO, USA) diluted 1:2,500 in blocking buffer was added to each well. The plates were incubated for $1 \mathrm{~h}$ at $37^{\circ} \mathrm{C}$ and washed. The bound antibody was detected after the addition of substrate ( $100 \mu \mathrm{L} ; 4.0 \mathrm{mg}$ of OPD [ortho-phenylenediamine] from Sigma Chemical Co. Saint Louis, USA) dissolved in $0.1 \mathrm{M}$ citrate phosphate buffer $\left(\mathrm{pH} \mathrm{5.0)}\right.$ and $4 \mu \mathrm{L}$ of $30 \% \mathrm{H}_{2} \mathrm{O}_{2}$. After incubation at room temperature for $20 \mathrm{~min}$ in the dark, the reaction was stopped by the addition of $1 \mathrm{NH}_{2} \mathrm{SO}_{4}$. The plates were read in an automatic ELISA plate reader (Molecular Devices, Sunnyvale, CA) at $\mathrm{A}_{492}$, and the final absorbance of each sample was plotted as the optical density at $492 \mathrm{~nm}\left(\mathrm{OD}_{492}\right)$ after the subtraction of the absorbance from the control well. The samples with a reading of $0.2 \mathrm{OD}_{492}$ units above the negative control absorbance were considered positive. A second assay was performed under the same conditions: each serum sample $(1: 80)$ was added to quadruplicate test wells containing antigen, and four blank wells containing no antigen.

\section{Gel electrophoresis and immunoblotting}

The TRP36 recombinant protein was subjected to 10\% SDS-PAGE and immunoblotting. The Bio-Rad Mini-Protean II apparatus was used with an SDS-PAGE Slab Gel, and the Bio-Rad Mini Trans-Blot Electrophoretic Transfer Cell was used for electroblotting (Bio-Rad Laboratories, Hercules, CA, USA). Briefly, $100 \mu \mathrm{L}$ of the purified TRP36 recombinant protein $(1 \mu \mathrm{g} / \mu \mathrm{L})$ was heated at $100^{\circ} \mathrm{C}$ for $10 \mathrm{~min}$ in sample buffer without 2-mercaptoethanol and centrifuged prior to being loaded in the stacking gel. Protein separation was performed on a $10 \%$ polyacrylamide gel (separating gel; $1.0 \mathrm{~mm}$ thickness) in Tris-glycine running buffer $(\mathrm{pH} 8.3)$ at $200 \mathrm{~V}$ until the dye front migrated to the bottom of the gel. A protein standard was included in one outside well for the determination of the protein mass (Amersham ${ }^{\mathrm{TM}} \mathrm{ECL}^{\mathrm{TM}}$ Rainbow ${ }^{\mathrm{TM}}$ Marker, Full Range, GE Healthcare Bio-Sciences Corp., USA). The proteins were electro transferred onto a nitrocellulose membrane (Millipore $0.2 \mu \mathrm{m}$ pore size) by the wet (tank) blotting method in Tris-glycine transfer buffer (pH 8.3) with $20 \%$ methanol for $1 \mathrm{~h}$ at $100 \mathrm{~V}$. After electrophoresis, the part of the membrane adjacent to the molecular weight markers was cut and stained with $0.1 \%$ Amido Black 10B for TRP36 protein visualization and to determine the electrophoretic mobility of the protein relative to that of the standard markers. The remaining part of the membrane was incubated with blocking buffer (PBS-5\% nonfat milk) for $1 \mathrm{~h}$, and after drying, it was cut into $5 \mathrm{~mm}$ lanes. The dog serum samples were diluted (1:80) in blocking buffer, and $1 \mathrm{~mL}$ was added to the membrane lanes. After $1 \mathrm{~h}$ at room temperature with slow rocking, the membranes were washed with PBS and incubated for $1 \mathrm{~h}$ with rabbit anti-dog IgG (whole molecule) peroxidase-conjugate (Sigma Chemical, Saint Louis, MO, USA) diluted 1:2,000 in blocking buffer. The membranes were washed with PBS, and the bound antibody was visualized by adding $5 \mathrm{mg}$ of DAB (3,3' diaminobenzidine - Sigma Chemical Co., Saint Louis, $\mathrm{MO}, \mathrm{USA}$ ) and $30 \% \mathrm{H}_{2} \mathrm{O}_{2}(10 \mu \mathrm{L})$ in $10 \mathrm{~mL}$ of PBS.

\section{Results}

The genomic DNA extracted from E. canis cultivated in DH82 cells was used as the template for PCR targeting a portion of the ehrlichial trp36 gene, which encodes the TRP36 protein. The PCR amplification of the ehrlichial template DNA resulted in a fragment of approximately $900 \mathrm{bp}$ as expected for the TRP36 coding sequence (Figure 1). The sequence of the fragment was $99.8 \%$ identical to the trp36 gene sequence of the $E$. canis São Paulo strain deposited in GenBank (accession number DQ146154), according to the similarity-searching program BLAST (http://www.ncbi.nlm.nih.gov/blast). After cloning the ehrlichial trp36 gene into the expression vector (pBAD/Thio-TOPO) and selecting the clones, a PCR was performed to confirm the insertion, by using a pair of primers (sense primer 1trp36SP and the pBAD reverse). The amplification corresponded to an amplicon of $900 \mathrm{bp}$ (Figure 2). The expression of the recombinant TRP36 protein was induced, and a large protein band with a molecular mass $<50 \mathrm{kDa}$ was observed by SDS-PAGE (Figure 3). After purification, this protein was analyzed by $10 \%$ SDS-PAGE under denaturing and nonreducing conditions, revealing a protein band with a molecular mass of $44 \mathrm{kDa}$, which was expected, since TRP36 surface protein in E. canis species have identical tandem repeats sequences, but they differ in the number of repeats (Figure 3).

The reactivity of the antibodies in dog sera with the recombinant TRP36 protein was assayed by an indirect ELISA. The recombinant protein was adsorbed onto plastic plates, and the sera from dogs previously identified as positive or negative for $E$. canis infection were used as sources of primary antibodies. The titration results showed that some of the positive sera interacted with the TRP36 protein even at a dilution of 1:640 $\left(O D_{492}\right.$ units higher than 0.2 , which was the $\mathrm{OD}_{492}$ value for negative sera diluted 1:40) (data not shown). The results obtained for some serum samples diluted 1:80 are shown in Figure 4. 


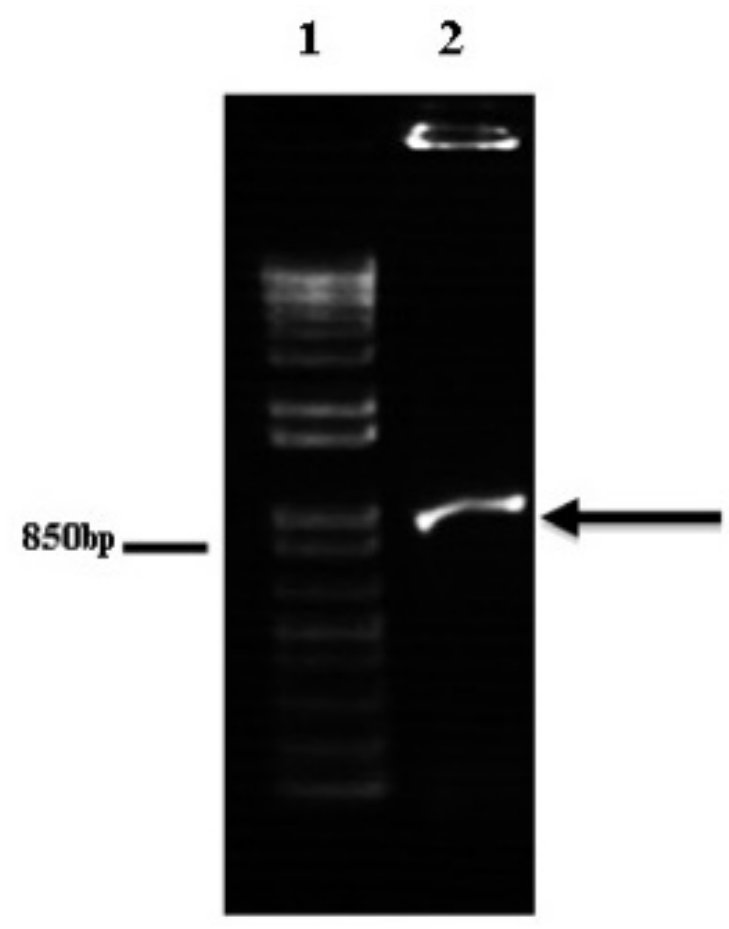

Figure 1. Agarose gel (0.8\%) electrophoresis showing a PCR product obtained from the amplification of ehrlichial template DNA with primers based on the trp36 gene sequence of the E. canis São Paulo strain cultivated in DH82 cells. Lane 1 - Molecular weight 1 Kb Plus DNA Ladder (Invitrogen); lane 2 - Amplicon from the trp36 gene (900 bp) that encodes the TRP36 protein. The band corresponding to the PCR product is indicated (arrow).

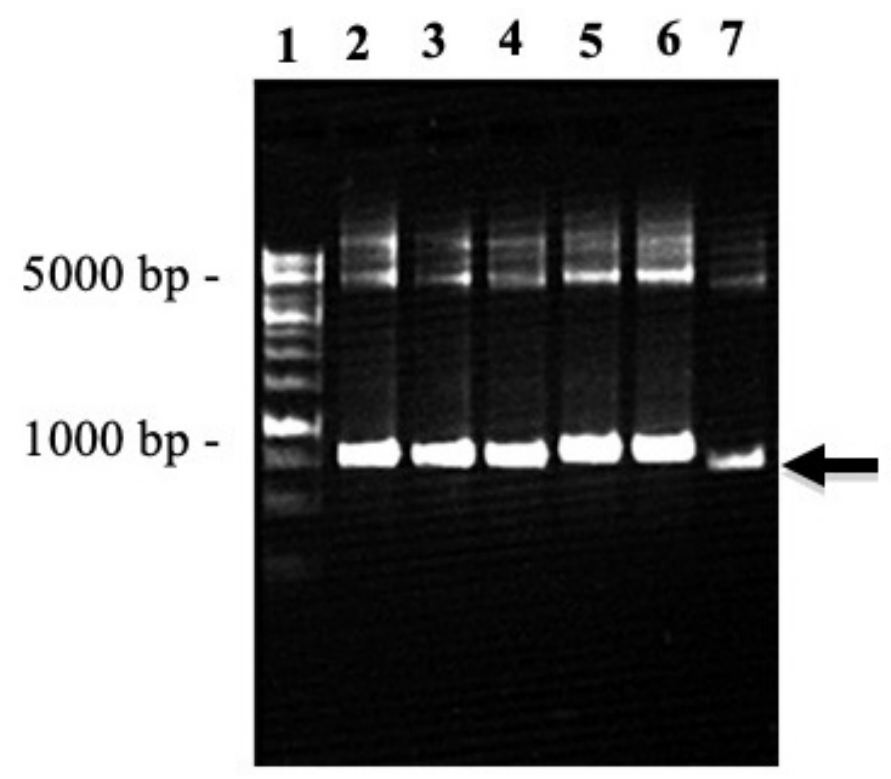

Figure 2. Agarose gel (0.8\%) electrophoresis of the PCR products of the gene encoding the TRP36 protein, cloned into the pBAD/Thio-TOPO vector. Lane 1 - Molecular weight $1 \mathrm{~kb}$ Plus DNA Ladder (Fermentas); lanes 2-6- PCR of positive clones screened by PCR with the sense primer $1 \operatorname{trp36SP}\left(5^{\prime}\right.$ - ATGCTTCATTTA ACA ACAGA - $\left.3^{\prime}\right)$ and an antisense primer located in the vector (pBAD reverse primer) provided in the Invitrogen kit (arrow); lane 7-gp36 gene amplicon of E. canis cultured in DH82 cells. The $900 \mathrm{bp}$ band corresponding to the trp36 gene PCR product is indicated (arrow).

All the serum samples were from dogs that had been tested positively for canine ehrlichiosis using PCR and the commercial ELISA kit SNAP ${ }^{\circledR}$ D ${ }^{\circledR}$ test. Six serum samples were positive from PCR and the serological test data. One sample (223) was positive from PCR, but negative from the serological test. Another five serum samples were positive from serological test only. Four samples were negative for all antigens on the SNAP®4DX ${ }^{\circledR}$ test kit as well as the PCR analysis. The results of the indirect ELISA, using recombinant TRP36 as an antigen, were comparable 


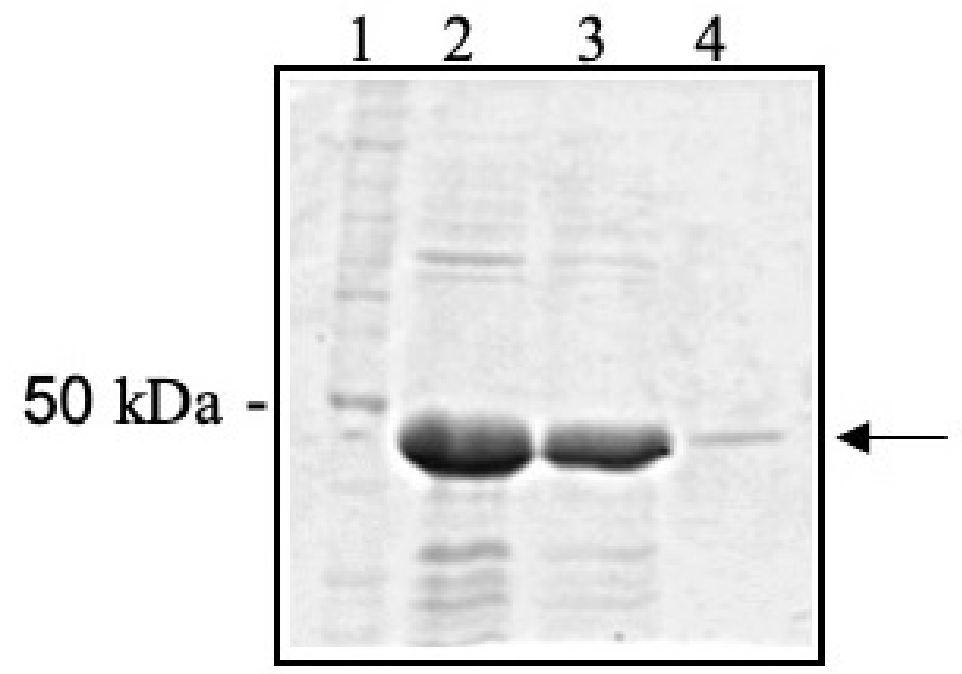

Figure 3. SDS-polyacrylamide gel electrophoresis showing the elution fractions from transformed $E$. coli $\mathrm{DH} 10 \mathrm{~B}$ lysate after the overexpression of recombinant TRP36 protein in the presence of $0.002 \%$ L-arabinose applied to His•Bind Resin, $\mathrm{Ni}$-charged. Lane 1- Molecular weight marker PageRuler Unstained Protein Ladder (Thermo Scientific); lanes 2 to 4 - elution fractions after applying buffer containing $500 \mathrm{mM}$ imidazole (arrow).

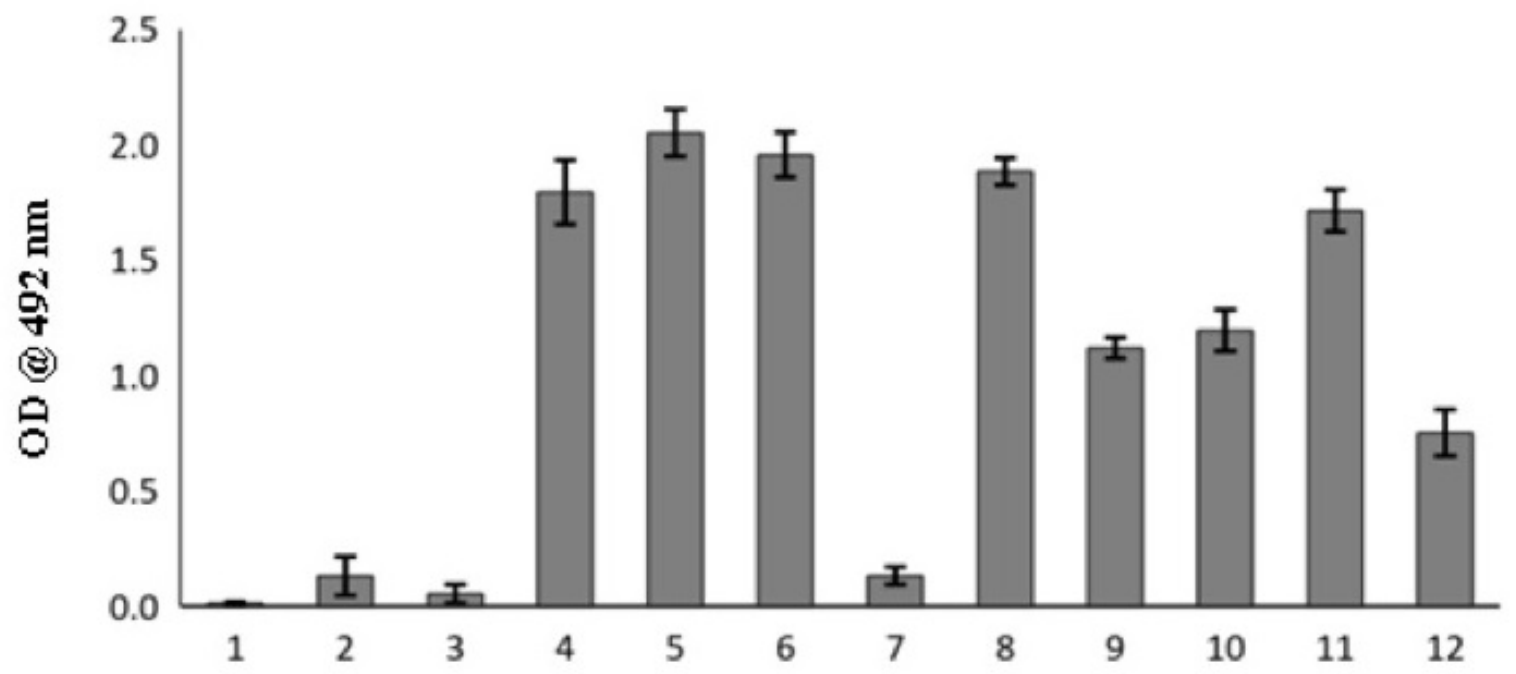

Figure 4. Detection of anti-Ehrlichia canis antibodies in sera from E. canis naturally infected dogs bound to the recombinant TRP36 as the antigen in indirect ELISA. Sera were diluted 1:80, and values were plotted as the $\mathrm{DO}_{490}$. Bars indicate the ELISA results for dog sera previously identified as negative and positive for $E$. canis infection by PCR and commercial kit (SNAP® ${ }^{\circledR D X}{ }^{\circledR}$ test). 1 - Conjugate control (no serum in wells); 2 and 3 - negative infection [PCR negative and SNAP ${ }^{8 D X}{ }^{\circledR}$ negative]; animals $n^{\circ} 360$ and 363 , respectively; bars 4, 5 and 6 - positive infection [PCR negative and SNAP ${ }^{\circledR} 4 D X^{\circledR}$ positive] Animals $n^{\circ} 200$, 337, and 341 respectively; 7 - positive infection [PCR positive and SNAP ${ }^{\circledR} 4 \mathrm{DX}^{\circledR}$ negative], animal $n^{\circ} 223 ; 8$ to 12 - positive infection [PCR positive and SNAP ${ }^{\circledR} 4 D X^{\circledR}$ positive], animals TbDog, ChDog, BIDog, BrDog, and CoDog. Standard deviations were calculated from quadruplicate assays.

to those obtained with the commercial test kit. The WB analysis of some serum samples showed the reactivity of the recombinant TRP36 protein (Table 1).

In the Western immunoblotting assay (Figure 5), the recombinant TRP36 protein was identified on the nitrocellulose membrane before the immunological reactions. A nitrocellulose strip next to the molecular weight markers was stained with a protein reagent (amid black), revealing a large protein band of $44 \mathrm{kDa}$. The reactivity of antibodies in the positive sera with this protein confirmed the antigenicity of the recombinant TRP36 protein, as previously shown by indirect ELISA. Two less prominent proteins, most likely molecular aggregates, were visualized near $102 \mathrm{kDa}$. The negative sera for antibodies to E. canis did not interact with any protein adsorbed onto the nitrocellulose membrane. 
Table 1. Comparison of the data of detection of $E$. canis infection by PCR and a commercial serological kit versus indirect ELISA and WB using recombinant TRP36 in naturally infected dogs.

\begin{tabular}{|c|c|c|c|c|}
\hline Doga & PCR & Serology ${ }^{b}\left(S^{\prime} A P^{\circledR} 4 x^{\circledR}\right)$ & ELISAc (TRP36 recomb.) & $W^{d}{ }^{d(T R P 36 ~ r e c o m b .) ~}$ \\
\hline 363 & - & - & - & - \\
\hline 360 & - & - & - & ND \\
\hline 368 & - & - & - & ND \\
\hline 220 & - & - & - & ND \\
\hline 200 & - & + & + & + \\
\hline 337 & - & + & + & + \\
\hline 341 & - & + & + & ND \\
\hline $358 *$ & - & + & + & ND \\
\hline $336^{* *}$ & - & + & + & ND \\
\hline 223 & + & - & - & - \\
\hline TbDog & + & + & + & + \\
\hline BIDog & + & + & + & ND \\
\hline ChDog & + & + & + & ND \\
\hline 460 & + & + & + & ND \\
\hline BrDog & + & + & + & + \\
\hline CoDog & + & + & + & ND \\
\hline
\end{tabular}

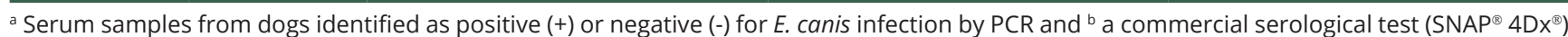
with total serum. ${ }^{c}$ Indirect ELISA and dWB with recombinant TRP36 protein as the antigen and (1:80) diluted dog sera. ND (not determined); * the dog was also infected with Leishmania; ** the dog was also infected with Anaplasma.

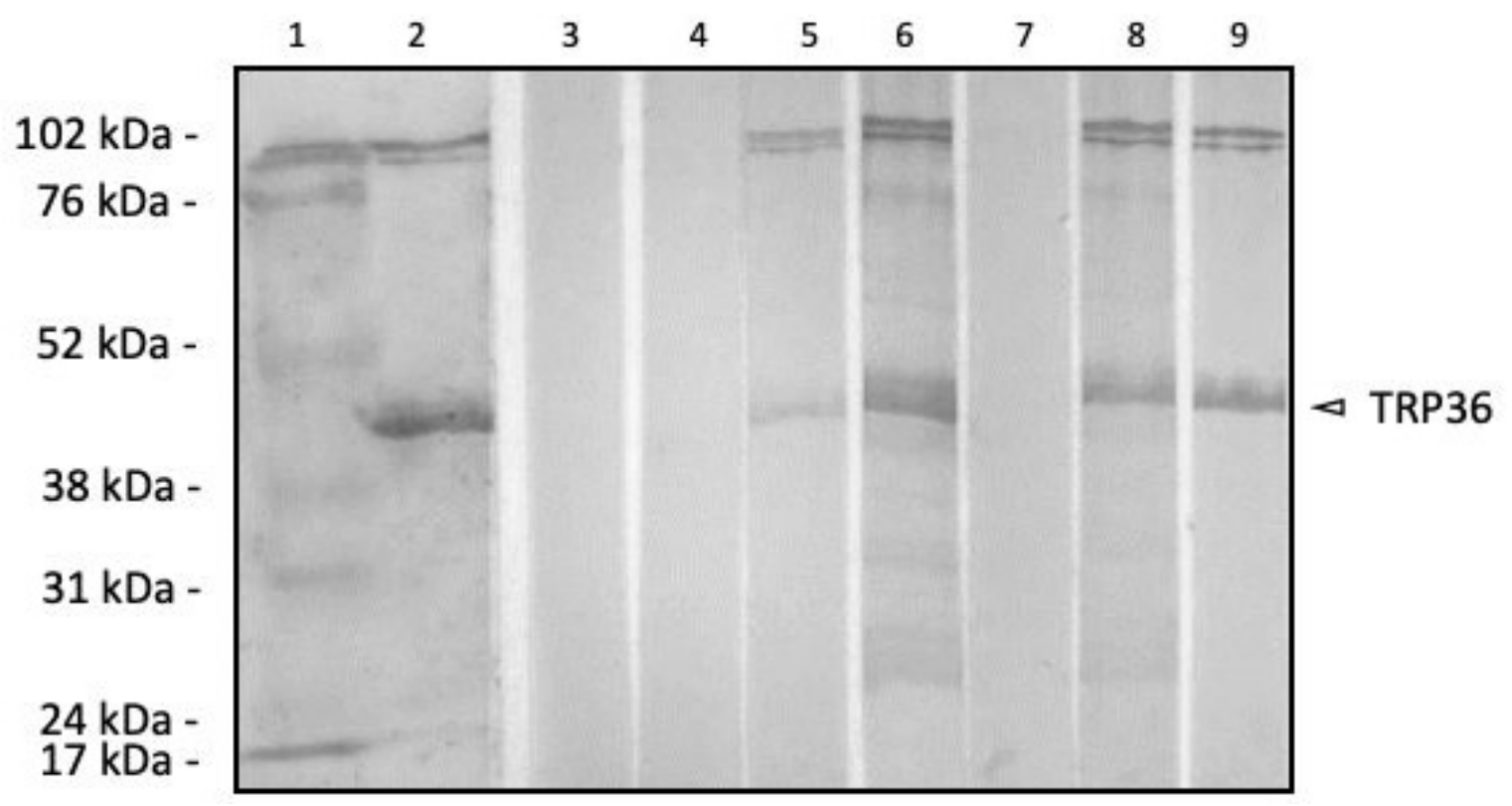

Figure 5. Western immunoblot of recombinant Ehlichia canis TRP36 with dog sera previously identified as negative or positive for E. canis infection by PCR and commercial kit (SNAP ${ }^{\circledR} 4 D X^{\circledR}$ tests). Lane 1 - Protein standard (AmershamTM ECLTM RainbowTM Marker, Full Range, GE Healthcare Bio-Sciences Corp., USA); lane 2- Positive control: TRP36 recombinant protein purified by metal chromatography; lane 3- Conjugate control (no serum); lane 4- Negative control: animal 363 negative for the infection in the PCR and SNAP ${ }^{\circledR} 4 D^{\circledR}$; lanes 5 and 6- Animals 200 and 337, respectively, positive for the infection in the SNAP ${ }^{\circledR} 4 D X^{\circledR}$, but negative in the PCR; lane 7- animal 223 positive for the infection in the PCR, but negative in the SNAP ${ }^{\circledR} 4 D^{\circledR}$; lanes 8 and 9: animals TbDog and BrDog, respectively, positive for the infection in the PCR and the SNAP ${ }^{\circledR} 4 D X^{\circledR}$. 


\section{Discussion}

$\mathrm{CME}$ is a serious infectious disease occurring in dogs from numerous regions of Brazil. Laboratory analyses for hematologic abnormalities and serum antibodies against Ehrlichia are used to confirm the clinical diagnosis of ehrlichiosis, but a serological assay is necessary to diagnose $E$. canis infections in dogs in Brazil. Although commercially available serodiagnostic tests exist, they are not routinely used due to their cost and the unavailability of the necessary laboratory facilities. Serologic tests to detect a dog's antibodies against Ehrlichia depend on the antigen used for sample analyses. IFA tests use $E$. canis in cell culture; methods based on enzyme-linked immunosorbent reagents use synthetic peptides. Recombinant DNA technology would be a great alternative method because it is possible to obtain considerable amounts of relatively pure and specific antigen samples (McBride et al., 2001).

Several studies showed the reactivity of $E$. canis recombinant proteins with serum antibodies from both experimentally and naturally infected dogs. This study describes the production of the TRP36 protein from the E. canis São Paulo strain using recombinant DNA technology to obtain an autochthonous antigen for the development of serologic tests. Comparisons of the different serological assays for the diagnosis of CME have revealed variations in sensitivity, specificity and accuracy, which are pivotal statistical attributes that can depend on the antigen used. In fact, even when using the same diagnostic method to test a relevant sample, some variations will occur depending on the antigen source. Aguirre et al. (2009) compared the results of IFA tests using three different $E$. canis strains as the antigen source (a commercial antigen, the $E$. canis Oklahoma strain and the E. canis Madrid strain). When comparing the antibody titer results, the differences between the Madrid strain and the other two antigen sources were statistically significant. In addition, a higher sensitivity of the IFA test has been observed when the autochthonous strain was used as the antigen. Aguiar et al. (2007b) have already observed similar results from the IFA tests for the $E$. canis Jaboticabal strain.

The Sao Paulo strain has been established in cell culture, and its molecular characterization showed that it is nearly identical to E. canis strains from other countries and continents (Aguiar et al., 2008; Aguiar et al., 2013). Aguiar et al. (2013) have identified two distinct major Brazilian genogroups and several subtypes based on the analysis of TRP36 and have suggested using the TRP36 protein for strain-specific vaccines and diagnostic methods. In this previous study, the recombinant TRP36 protein presented a molecular weight lower than $50 \mathrm{kDa}$, which according to Doyle et al. 2006 is expected because several surface glycoproteins have been identified in Ehrlichia species and in E. canis the TRP36 had identical tandem repeat sequences, but the differ in the number of repeats. Even though, in the Western blotting the recombinant proteins was recognized by dogs positive serum.

In the present study, the TRP36 recombinant protein, derived from E. canis São Paulo strain, was recognized by antibodies from naturally infected dogs from Rio de Janeiro state. The serum samples used to show the antigenicity of this protein were previously tested for $E$. canis infection by PCR and serologic assay using the commercial serological test SNAP ${ }^{\circledR} 4 \mathrm{Dx}^{\circledast}$. The results obtained by the indirect ELISA were comparable to those showed by the SNAP ${ }^{\circledR} 4 \mathrm{Dx}^{\circledR}$ test. The recombinant protein was recognized in a western immunoblotting experiment, which is considered to be a more specific test for revealing antigenic proteins from etiologic agents associated with different pathologies (Rikihisa et al., 1994). It is good to emphasize that the clinical symptoms of the evaluated animal should always be considered, since the serological tests, such as ours, could indicate that the dog has the infection, or had contact with the pathogen and, still have antibodies against it circulating. Conversely, the PCR test indicate presence or absence of the pathogen, so in all five serum samples used in our study negative for PCR and positive in the WB with the recombinant TRP36 and SNAP ${ }^{\circledR} 4 \mathrm{Dx}^{\circledR}$ it could indicate an actual infection or not. Hence, the veterinarian should keep in mind that clinical exams are extremely important and that only one diagnostic test is not enough to determine if a dog has Ehrlichiosis or not and, the complementation of a molecular test and a serological test will be extremely helpful to close the diagnostic.

Considering the previously demonstrated differences among the recent $E$. canis isolates from other Brazilian regions (Aguiar et al., 2016), it is necessary to evaluate the serum reactivity of naturally infected dogs from those regions to verify whether this recombinant protein is also recognized. Experiments to develop a dot-ELISA test using this recombinant protein as the antigen are the next step to produce a reliable, affordable and useful diagnostic tool for ehrlichiosis in Brazil.

\section{Acknowledgements}

We thank Dr. J.M. Peralta of the Departamento de Imunologia, Instituto de Microbiologia Paulo de Góes, Universidade Federal do Rio de Janeiro - UFRJ, Rio de Janeiro, RJ, Brazil, for allowing us to use his laboratory facilities. The authors gratefully acknowledge the Brazilian agencies Fundação de Amparo à Pesquisa do Estado de São Paulo - FAPESP; Fundação Oswaldo Cruz; Conselho Nacional de Desenvolvimento Científico e Tecnológico (CNPq), 
Fundação de Amparo à Pesquisa do Estado do Rio de Janeiro (FAPERJ) and the Coordenação de Aperfeiçoamento de Pessoal de Nível Superior - Brasil (CAPES) - Finance Code 001 for supporting this study.

\section{References}

Aguiar DM, Cavalcante GT, Pinter A, Gennari SM, Camargo LMA, Labruna MB. Prevalence of Ehrlichia canis (Rickettsiales: Anaplasmataceae) in dogs and Rhipicephalus sanguineus (Acari: Ixodidae) ticks from Brazil. J Med Entomol 2007a; 44(1): 126-132. http://dx.doi.org/10.1603/0022-2585(2007)44[126:POECRA]2.0.CO;2. PMid:17294930.

Aguiar DM, Hagiwara MK, Labruna MB. In vitro isolation and molecular characterization of an Ehrlichia canis strain from São Paulo, Brazil. Braz J Microbiol 2008; 39(3): 489-493. http://dx.doi.org/10.1590/S1517-83822008000300014. PMid:24031251.

Aguiar DM, Saito TB, Hagiwara MK, Machado RZ, Labruna MB. Serological diagnosis of canine monocytic ehrlichiosis with Brazilian antigen of Ehrlichia canis. Cienc Rural 2007b; 37(3): 796-802. http://dx.doi.org/10.1590/S0103-84782007000300030.

Aguiar DM, Zhang X, Braga IA, Taques II, McBride JW. Detection of genotype-specific Ehrlichia canis exposure in Brazilian dogs by TRP36 peptide ELISA. Ticks Tick Borne Dis 2016; 7(1): 142-145. http://dx.doi.org/10.1016/j.ttbdis.2015.10.003. PMid:26482949.

Aguiar DM, Zhang X, Melo AL, Pacheco TA, Meneses AM, Zanutto MS, et al. Genetic diversity of Ehrlichia canis in Brazil. Vet Microbiol 2013; 164(3-4): 315-321. http://dx.doi.org/10.1016/j.vetmic.2013.02.015. PMid:23490559.

Aguirre E, Ayllón T, Sainz A, Amusategui I, Villaescusa A, Rodríguez-Franco F, et al. Results from an indirect fluorescent antibody test using three different strains of Ehrlichia canis. Vet J 2009; 182(2): 301-305. http://dx.doi.org/10.1016/j.tvjl.2008.07.013. PMid:18760641.

Alves RN, Rieck SE, Ueira-Vieira C, Labruna MB, Beletti ME. Isolation, in vitro propagation, genetic analysis, and immunogenic characterization of an Ehrlichia canis strain from southeastern Brazil. J Vet Sci 2014; 15(2): 241-248. http://dx.doi.org/10.4142/ jvs.2014.15.2.241. PMid:24136211.

Birnboim HC, Doly J. A rapid alkaline extraction procedure for screening recombinant plasmid DNA. Nucleic Acids Res 1979; 7(6): 1513-1523. http://dx.doi.org/10.1093/nar/7.6.1513. PMid:388356.

Cárdenas AM, Doyle CK, Zhang X, Nethery K, Corstvet RE, Walker DH, et al. Enzyme-linked immunosorbent assay with conserved immunoreactive glycoproteins gp36 and gp19 has enhanced sensitivity and provides species-specific immunodiagnosis of Ehrlichia canis infection. Clin Vaccine Immunol 2007; 14(2): 123-128. http://dx.doi.org/10.1128/CVI.00361-06. PMid:17151186.

Cohn LA. Ehrlichiosis and related infections. Vet Clin North Am Small Anim Pract 2003; 33(4): 863-884. http://dx.doi.org/10.1016/ S0195-5616(03)00031-7. PMid:12910747.

Donatien A, Lestoquard F. Existence en Algérie d'une Rickettsia du chien. Bull Soc Pathol Exot 1935; 28: 418-419.

Doyle CK, Cardénas AM, Aguiar DM, Labruna MB, Ndip LM, Yu XJ, et al. Molecular characterization of E. canis gp36 and E. chaffeensis gp47 tandem repeats among isolates from different geographic localization. Ann N Y Acad Sci 2005; 1063(1): 433-435. http:// dx.doi.org/10.1196/annals.1355.079. PMid:16481555.

Doyle CK, Nethery KA, Popov VL, McBride JW. Differentially expressed and secreted major immunoreactive protein orthologs of Ehrlichia canis and E. chaffeensis elicit early antibody responses to epitopes on glycosylated tandem repeats. Infect Immun 2006; 74(1): 711-720. http://dx.doi.org/10.1128//Al.74.1.711-720.2006. PMid:16369028.

Ferreira RF, Cerqueira AMF, Castro TX, Ferreira EO, Neves FPG, Barbosa AV, et al. Genetic diversity of Ehrlichia canis strains from naturally infected dogs in Rio de Janeiro, Brazil. Rev Bras Parasitol Vet 2014; 23(3): 301-308. http://dx.doi.org/10.1590/S198429612014055.

Groves MG, Dennis GL, Amyx HL, Huxsoll DL. Transmission of Ehrlichia canis to dogs by ticks (Rhipicephalus sanguineus). Am J Vet Res 1975; 36(7): 937-940. PMid:1147359.

Harrus S, Waner T. Diagnosis of canine monocytotropic ehrlichiosis (Ehrlichia canis): an overview. Vet J 2011; 187(3): 292-296. http://dx.doi.org/10.1016/j.tvjl.2010.02.001. PMid:20226700.

Kuehn NF, Gaunt SD. Clinical and hematologic findings in canine ehrlichiosis. J Am Vet Med Assoc 1985; 186(4): 355-358. PMid:3972694.

Laemmli UK. Cleavage of structural proteins during the assembly of the head of bacteriophage T4. Nature 1970; 227(5259): 680685. http://dx.doi.org/10.1038/227680a0. PMid:5432063.

McBride JW, Corstvet RE, Breitschwerdt EB, Walker DH. Immunodiagnosis of Ehrlichia canis infection with recombinant proteins. J Clin Microbiol 2001; 39(1): 315-322. http://dx.doi.org/10.1128/JCM.39.1.315-322.2001. PMid:11136790.

McBride JW, Corstvet RE, Gaunt SD, Boudreaux C, Guedry T, Walker DH. Kinetics of Antibody Response to Ehrlichia canis immunoreactive proteins. Infect Immun 2003; 71(5):2516-2524. http://dx.doi.org/10.1128/IAl.71.5.2516-2524.2003. PMid:12704123. 
McBride JW, Corstvet RE, Gaunt SD, Chinsangaram J, Akita GY, Osburn BI. PCR detection of acute Ehrlichia canis infection in dogs. J Vet Diagn Invest 1996; 8(4): 441-447. http://dx.doi.org/10.1177/104063879600800406. PMid:8953528.

McBride JW, Doyle CK, Zhang X, Cardénas AM, Popov VL, Nethery KA, et al. Identification of a glycosylated Ehrlichia canis 19-Kilodalton major immunoreactive protein with a species-specific serine-rich glycopeptide epitope. Infect Immun 2007; 75(1): 74-82. http://dx.doi.org/10.1128/IAI.01494-06. PMid:17088359.

McBride JW, Yu XJ, Walker DH. Molecular cloning of the gene for a conserved major immunoreactive 28-kilodalton protein of Ehrlichia canis: a potential serodiagnostic antigen. Clin Diagn Lab Immunol 1999; 6(3): 392-399. http://dx.doi.org/10.1128/ CDLI.6.3.392-399.1999. PMid:10225842.

McBride JW, Zhang X, Wakeel A, Kuriakose JA. Tyrosine-phosphorylated Ehrlichia chaffeensis and Ehrlichia canis tandem repeat orthologs contain a major continuous cross-reactive antibody epitope in lysine-rich repeats. Infect Immun 2011; 79(8): 3178 -3187. http://dx.doi.org/10.1128/IAI.01347-10. PMid:21606187.

Nyindo MB, Ristic M, Huxsoll DL, Smith AR. Tropical canine pancytopenia: in vitro cultivation of the causative agent- Ehrlichia canis. Am J Vet Res 1971; 32(11): 1651-1658. PMid:4107760.

O'Connor TP, Hanscom JL, Hegarty BC, Groat RG, Breitschwerdt EB. Comparison of an indirect immunofluorescence assay, western blot analysis, and a commercially available ELISA for detection of Ehrlichia canis antibodies in canine sera. Am J Vet Res 2006; 67(2): 206-210. http://dx.doi.org/10.2460/ajvr.67.2.206. PMid:16454622.

Ohashi N, Unver A, Zhi N, Rikihisa Y. Cloning and characterization of multigenes encoding the immunodominant 30-kilodalton major outer membrane proteins of Ehrlichia canis and application of the recombinant protein for serodiagnosis. J Clin Microbiol 1998; 36(9): 2671-2680. http://dx.doi.org/10.1128/JCM.36.9.2671-2680.1998. PMid:9705412.

Rikihisa Y, Ewing SA, Fox JC. Western immunoblot analysis of Ehrlichia chaffeensis, E. canis, or E. ewingii infections in dogs and humans. J Clin Microbiol 1994; 32(9): 2107-2112. http://dx.doi.org/10.1128/JCM.32.9.2107-2112.1994. PMid:7814533.

Rikihisa Y. Cross-Reacting Antigens between Neorickettsia helminthoeca and Ehrlichia Species, shown by Immunofluorescence and Western Immunoblotting. J Clin Microbiol 1991; 29(9): 2024-2029. http://dx.doi.org/10.1128/JCM.29.9.2024-2029.1991. PMid:1774330.

Ristic M, Holland CJ. Canine Ehrlichiosis. In: Woldehiwet Z, Ristic M, editors. Rickettsial and Chlamydial Diseases of Domestic Animals. Oxford: Pergamon Press; 1993. p. 169-186.

Rozen S, Skaletsky HJ. Primer3 on the WWW for general users and for biologist programmers. In: Misener S, Krawetz S, editors. Bioinformatics Methods and Protocols: Methods in Molecular Biology. Totowa, NJ: Humana Press; 2000. p. 365-386.

Torres HM, Massard CL, Figueiredo MJ, Ferreira T, Almosny NRP. Isolamento e propagação da Ehrlichia canis em células DH82 e obtenção de antígeno para a reação de imunofluorescência indireta. Rev Bras Cienc Vet 2002; 9(2): 77-82. http://dx.doi. org/10.4322/rbcv.2015.233.

Vieira RFC, Biondo AW, Guimarães AM, Santos AP, Santos RP, Dutra LH, et al. Ehrlichiosis in Brazil. Rev Bras Parasitol Vet 2011; 20(1): 1-12. http://dx.doi.org/10.1590/S1984-29612011000100002. PMid:21439224.

Wellman ML, Krakowka S, Jacobs RM, Kociba GJ. A macrophage-monocyte cell line from a dog with malignant histiocytosis. In Vitro Cell Dev Biol 1988; 24(3): 223-229. http://dx.doi.org/10.1007/BF02623551. PMid:3350786.

Zweygarth E, Cabezas-Cruz A, Josemans Al, Oosthuizen MC, Matjila PT, Lis K, et al. In vitro culture and structural differences in the major immunoreactive protein gp36 of geographically distant Ehrlichia canis isolates. Ticks Tick Borne Dis 2014; 5(4): 423-431. http://dx.doi.org/10.1016/j.ttbdis.2014.01.011. PMid:24713279. 